$$
\begin{gathered}
F-601-851 E 10484 \\
\text { DOEIIE } 10484--T_{2}
\end{gathered}
$$
IAEA FELLOWSHIP PROGRAM

\title{
1997 REPORT ON
}

\section{UNITED STATES PARTICIPANTS}

\author{
National Research Council \\ National Academy of Sciences \\ 2101 Constitution Ave., NW \\ Washington, DC 20418
}




\section{DISCLAIMER}

This report was prepared as an account of work sponsored by an agency of the United States Government. Neither the United States Government nor any agency thereof, nor any of their employees, make any warranty, express or implied, or assumes any legal liability or responsibility for the accuracy, completeness, or usefulness of any information, apparatus, product, or process disclosed, or represents that its use would not infringe privately owned rights. Reference herein to any specific commercial product, process, or service by trade name, trademark, manufacturer, or otherwise does not necessarily constitute or imply its endorsement, recommendation, or favoring by the United States Government or any agency thereof. The views and opinions of authors expressed herein do not necessarily state or reflect those of the United States Government or any agency thereof. 


\section{DISCLAIMER}

Portions of this document may be illegible in electronic image products. Images are produced from the best available original document. 


\section{EXECUTIVE SUMMARY}

During the period of performance, January 1, 1997 through December 31,1997 , the National Research Council oversaw 505 man-months of technical training. During 1997, 160 Fellows from 40 countries were on tenure in U.S. institutions for training in the peaceful applications of nuclear energy. Of these, 36 were supported by U.S. funds (Type II) and 124 were supported by IAEA or UNDP program funds (80 Type I and 44 Type III Scientific Visitors). The Fellows who received training during the year attended 42 universities, 33 Federal and State Facilities, 20 medical institutions, 13 other institutions, and 2 utilities. Eleven fellows also attended English language school in this country prior to their technical training program.

The proportion of women participants trained as regular Fellows (Type I and Type II) in the U.S. in 1997 was $23 \%$, an increase of $4 \%$ compared to the previous year. Of the Scientific Visitors, $34 \%$ were women, an increase of $5 \%$ compared to the previous year.

The leading fields of study in which the regular Fellows (Type I and Type II) were trained during 1997 were Nuclear Safety with 29\% and Agricultural Applications with 27\% of the regular Fellows. These were followed by programs in Medical Applications with 17\%, Biological Applications with $11 \%$ and Nuclear Engineering and Technology with $9 \%$. The remaining 18\% were divided between Nuclear Physics and Chemistry, Biological Applications, Industrial and Hydrological Applications, and General Atomic Energy Development.

Agricultural Applications was also the major field of study undertaken by the Scientific Visitors and made up 34\% of those awards. Safety in Nuclear Energy made up 20\%, Medical Applications made up 14\% of those awards, and the number of SV's in each of the remaining fields was considerably smaller.

There have been many changes in participation among the 86 countries that have sent Fellows to the U.S. during the 40-year history of the program. Historically, the number of participants from countries in the Asia and Pacific region equaled those of all other regions, making up almost $50 \%$ of all Fellows trained. In 1997, number of participants from countries in East Asia and Pacific decreased from $51 \%$ to $34 \%$, with proportion of participants from Europe (mainly Eastern Europe) and West Asia at 26\%. Number of participants from Latin America increased from $12 \%$ in 1996 to $26 \%$ in 1997.

Thos. C. Rozzell, Sc.D.

Director, Fellowship Program

Office of Scientific and Engineering Personnel
Eliza I. Wojtaszek

Technical Placement Officer

IAEA Fellowship Program 


\section{CONTENTS}

Executive Summary $\quad$ i

General Information 1

$\begin{array}{ll}\text { Programs } & 1\end{array}$

Regular Fellowship Program 1

Scientific Visitor Program 2

Role of the National Research Council 2

Administrative Services $\quad 3$

$\begin{array}{ll}\text { Demographics and Statistics } & 4\end{array}$

Man-Months $\quad 4$

Academic Background 4

Age 5

Gender 5

Home Countries $\quad 6$

$\begin{array}{ll}\text { Fields of Study } & 7\end{array}$

$\begin{array}{ll}\text { Institutions Providing Training } & 7\end{array}$

Length of Tenure $\quad 8$

$\begin{array}{ll}\text { Appendix Tables } & 10\end{array}$ 


\title{
FELLOWSHIP TRAINING AND RESEARCH PROGRAM IN NUCLEAR SCIENCE INTERNATIONAL ATOMIC ENERGY AGENCY, VIENNA, AUSTRIA
}

\author{
PARTICIPANTS IN THE UNITED STATES - 1997 ANNUAL REPORT
}

\section{General Information}

The International Atomic Energy Agency (IAEA) Fellowship Program began in April 1958 as a part of the Agency's Technical Cooperation (TC) Program. Through the TC Program, the IAEA provides technical assistance to meet the needs of recipient countries and to bring about a substantial transfer of technology. This is done by providing experts, equipment, fellowships, and training courses. This report addresses the U.S. component of the fellowship program. These fellowships provide opportunities for research and training of scientists, engineers and physicians from developing countries in the peaceful application of nuclear energy. The fellowships are awarded to persons who are, or soon will be, trusted with responsibilities that are important to the development of their countries.

Resources for the program are made available through contributions of the Member States to the Agency's General Fund and from the United Nations Development Program (UNDP) Fund. Certain Member States, the United States being one, also provide additional funds for Fellowships at their own institutions.

The Fellowships are awarded by the Agency from applications submitted to it by Member States. Candidates are selected on the basis of educational and professional qualifications, their foreign language proficiency, the needs of the nation concerned, the number of fellowships previously awarded to nationals of that State, and on evidence and assurance that upon their return home, the candidate's training will be utilized effectively for a period of not less than two years.

\section{Programs}

\section{Regular Fellowship Program}

Fellowship awards are classified into two groups, those financed by the IAEA General Fund or the UNDP Fund (Type I Fellowships and Scientific Visits), and those offered by Member States (Type II Fellowships). In placing individuals, preference is given to applicants from countries that are signatories to the Treaty on Non-Proliferation of Nuclear Weapons or to the Treaty for the Prohibition of Nuclear Weapons in Latin America.

The fellowships are normally awarded for periods of one month to one year. Extensions may be granted under certain circumstances. Generally, twenty-four months is the maximum time a Fellow may be in the program, although short extensions beyond this time 
have been granted. All extensions require the approval of the International Atomic Energy Agency and the Fellow's government as well as that of the National Research Council.

During 1997, 80 Type I and 36 Type II Fellows either completed their training or were on tenure.

\section{$\underline{\text { Scientific Visitor Program }}$}

In addition to the Type I and Type II fellowships, each year a number of Scientific Visitors (Type III Fellows) visit the U.S. for short periods (less than a month). Type III awards are granted to more experienced scientists and engineers to enable them to:

1) study new developments in nuclear science and technology and review current research;

2) observe organizational aspects and functioning of special services, training programs, and schools; and

3) confer with experts working in their particular field of interest.

The awards are intended to enhance the visitor's professional qualifications and thereby contribute more effectively to their country's scientific and technological progress.

Scientific Visitors often visit several institutions while in the U.S. and many also attend technical meetings of professional societies. During 1997, 44 persons came to the United States under this part of the program and visited 47 institutions during their stays.

\section{Role of the National Research Council}

The IAEA Fellowship Program in the United States is administered by the National Research Council (NRC) ${ }^{*}$ through the Office of Scientific and Engineering Personnel (OSEP). In 1997, the staff consisted of Dr. Tom Rozzell, Director of the Fellowship Office, Ms. Eliza Wojtaszek, Technical Program Officer, Ms. Alicia Kraft, Program Supervisor, Ms. Mary Ann Pryor and Ms. Bina Russell, Fellowship Program Coordinators, and Ms. Barbara Kneebone and Ms. Amy Dowd, Program Assistants. We operate under a grant from the U.S. Department of Energy with funds supplied by the U.S. Department of State (DOS).

\footnotetext{
* The National Research Council is the operating entity of the National Academies of Science and Engineering and the Institute of Medicine.
} 
A committee chaired by the Bureau of International Organization Affairs (IO) in DOS and comprising representatives of other offices in DOS and members from the Department of Energy, the Nuclear Regulatory Commission, and the Arms Control and Disarmament Agency reviews the applications of the candidates whom the IAEA requested be trained in the U.S. Those applications which are approved by IO for placement are forwarded to the NRC which then handles all administrative aspects of the training as indicated below.

\section{Administrative Services}

The administration of all fellowships includes:

--setting up a file and a computer record for each candidate.

--evaluating the English language capability of each candidate and recommending one or more months of intensive English schooling in the U.S. when necessary.

--arranging a training program with a suitable advisor and institution appropriate for the candidate's educational background and program objectives.

--recommending these assignments to the IAEA for acceptance.

--providing the candidate with a completed Certification of Eligibility for Exchange-Visitor Status (USIA Form IAP-66) so that s/he can obtain a visa.

--informing the advisor of arrival details and any changes to the program.

--receiving, tracking, and reviewing reports of Fellows' activities and transmitting copies to the Agency.

--assisting Fellows and advisors with mid-program travel, extension requests, health insurance questions and any other problems or questions that arise.

--maintaining records and reports on administered fellowships and scientific visits.

--monthly status reports to IAEA.

For Type II Fellows, the administration also includes:

--arranging and paying for travel to and from the training site. 
--paying, during the period of the tenure, the: maintenance allowance book allowance training and tuition expenses to the host institution health and accident insurance worker's compensation insurance excess baggage/shipping allowance.

--assisting with financial and other arrangements in connection with midprogram travel to scientific meetings or field trips in the U.S.

The maintenance allowance ranges from $\$ 1,500$ to $\$ 1,800$ per month depending on the cost of living in the Fellow's geographical training location, with the first month allowance at $\$ 3,600$. The book allowance is $\$ 80$ per month, and the termination allowance is $\$ 100$ for a duration of tenure less than 6 months, and $\$ 200$ for a duration of tenure of six months or more. No provision is made for dependents in the program.

As can be seen, the National Research Council performs most of the same administrative services for Type I Fellows and Scientific Visitors as for the Type II Fellows. In addition, for the convenience of the IAEA and to expedite certain functions, the NRC pays certain expenses for Type I Fellows and SV's and is reimbursed by the IAEA.

Table A-1 (see Appendix) shows how many Fellows and applications the NRC managed in 1997.

\section{Demographics and Statistics}

\section{$\underline{\text { Man-Months }}$}

Table 1 shows how many man-months of training we managed in 1997 and in 1996. As can be seen, there were decreases in each of the categories.

Table 1. Man-Months of Training

\begin{tabular}{rrrrr}
\hline & Type I & Sci Vstrs & Type II & Total \\
\hline 1997 & 376 & 30 & 99 & 505 \\
1996 & 782 & 25 & 658 & 1465 \\
\hline
\end{tabular}




\section{Academic Background}

The nominees for IAEA Fellowships have an academic background of at least a bachelor's degree or its equivalent in training and experience. The distribution of educational levels of regular(Type I \& II) Fellows is shown in Figure 1 and in Table A-2. This data shows that $71 \%$ of them had graduate degrees (M.S., Ph.D., M.D. or D.V.M). Of Type III Fellows, $73 \%$ held graduate degrees.

Figure 1. Education Level of Type I and II Fellows

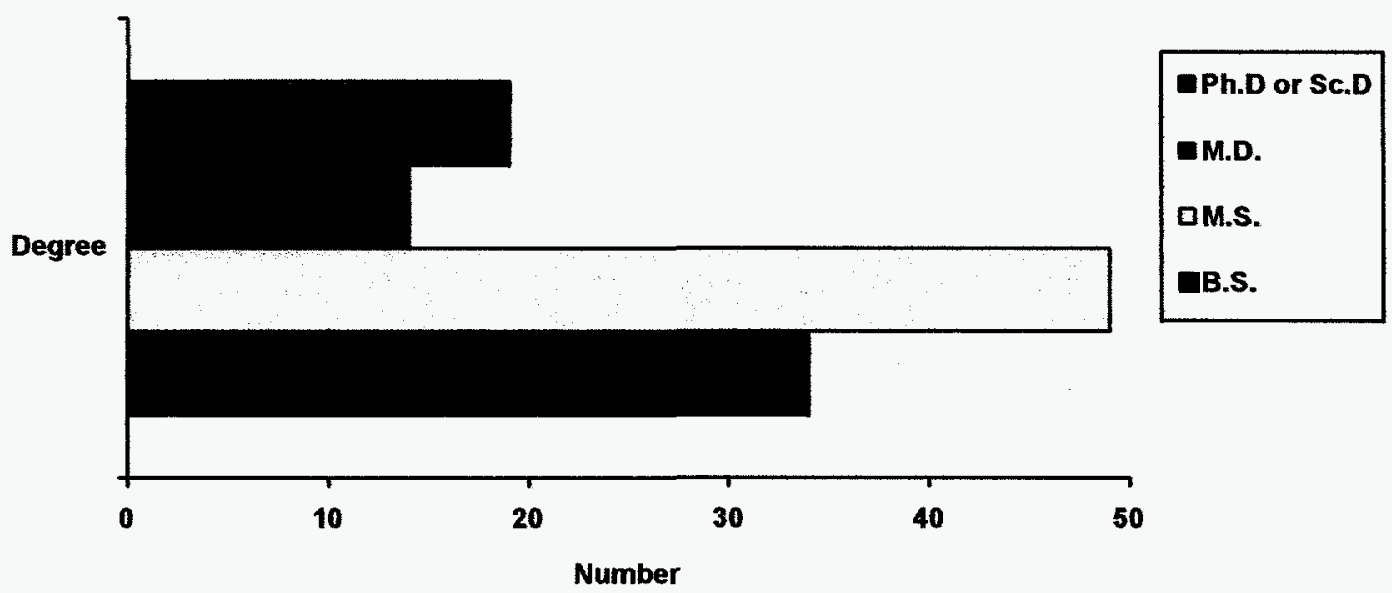

$\underline{\text { Age }}$

The distribution of ages among the Fellows who were active during 1997 is shown in Figure 2 and also in Table A-2. 76\% of the Type I and II Fellows were between the ages of 30 and 44 years. On the other hand, only $39 \%$ of the Type III Scientific Visitors were in that age range, and $55 \%$ were over age 44 . This is consistent with the fact that the scientific visits are designed for the more senior people in their field. 
Figure 2. Age Ranges of Fellows

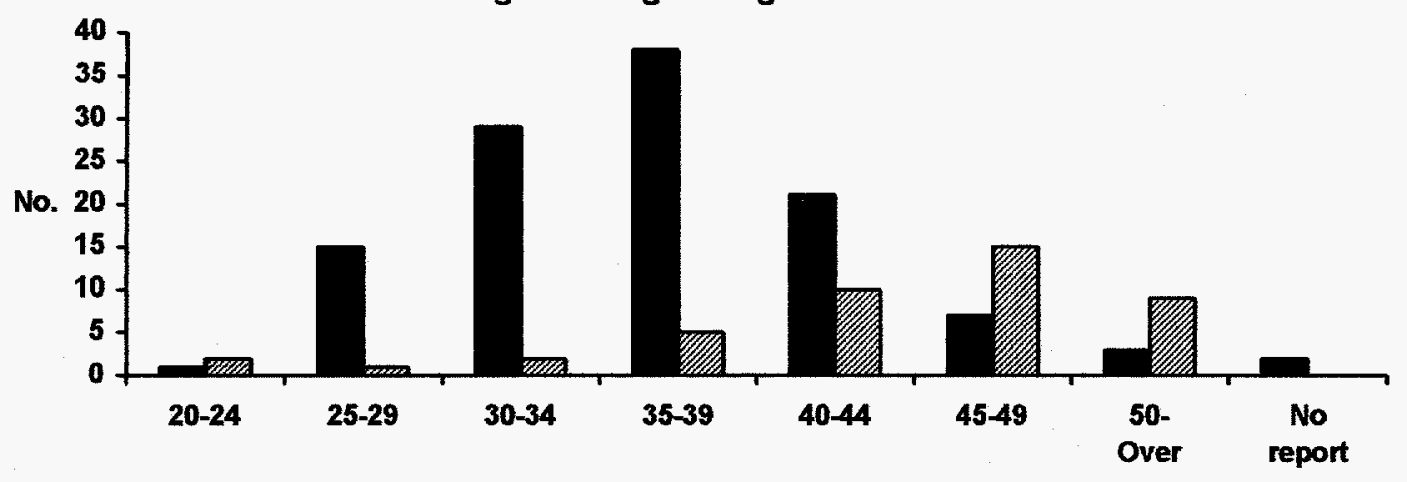

Age Range

Gender

The distribution by gender is also shown in Table A-2. 23\% of the regular Fellows were female in 1997, an increase of $4 \%$ compared to 1996 . Of the Scientific Visitors, $34 \%$ were women, an increase of $5 \%$ compared to the previous year.

\section{Home Countries}

Over the years there have been participants in the program from approximately 88 countries. The countries sending Fellows to the U.S. have changed through the years as their need for and ability to utilize nuclear technology changed. A number of countries that required trained manpower in the early years of the program are now assisting with the training of Fellows from less developed countries.

The home countries of the Fellows and SV's who were here during 1997 is shown in Table A-3. We hosted Fellows and SV's from 40 countries. Of those, 9 countries sent only 1 and 25 sent between 2 and 7 Fellows. Brazil sent 17 fellows, Egypt sent 14 fellows, Republic of Korea sent 12 fellows, Indonesia sent 11 fellows, Turkey sent 10 fellows, and Malaysia sent 8 fellows. These six countries thus accounted for $\mathbf{4 5}$ percent of all Fellows and SV's trained in the U.S.

The geographical distribution is shown in Figure 3. Number of participants from countries in the East Asia and Pacific regions decreased from 51\% in 1996 to 34\% of the total in 1997. The proportion of participants from Europe (mainly Eastern Europe) and West Asia is at $26 \%$. Number of participants from Latin America increased from $12 \%$ in 1996 to $26 \%$ in 1997. 


\section{Figure 3. Geographical Distribution of Fellows}

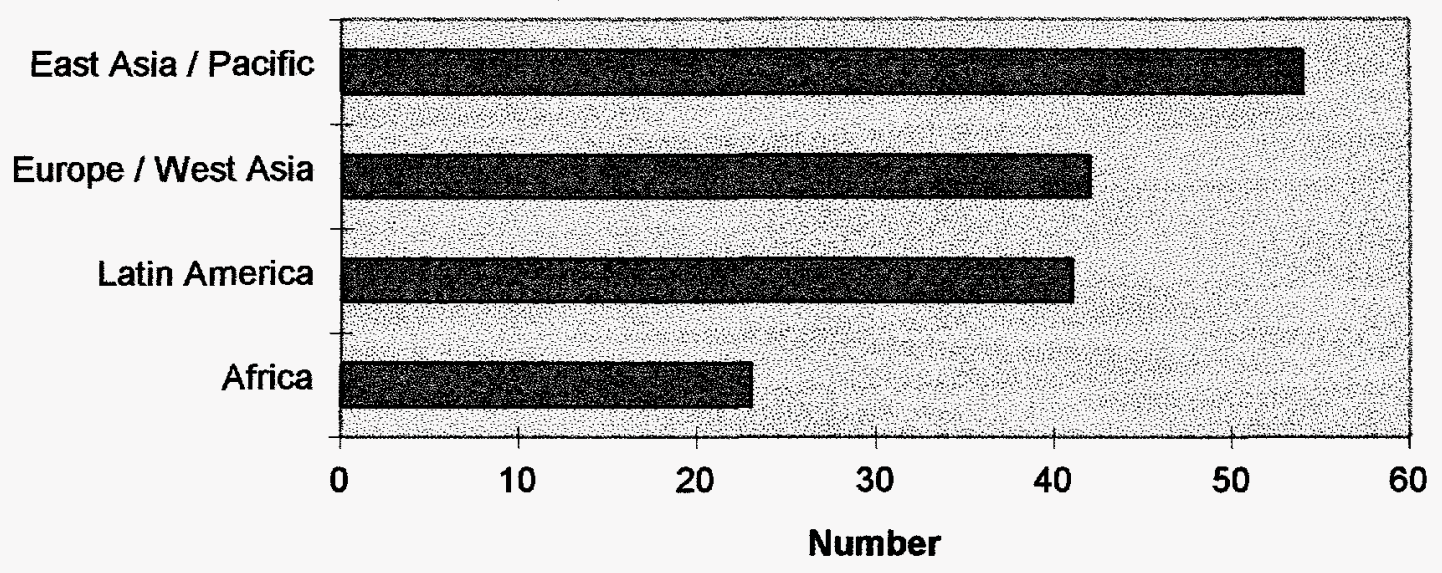

Fields of Study

The principal fields in which the regular Fellows were trained during 1997 were Nuclear Safety (29\%) and Agricultural Applications (27\%). These were followed by programs in Medical Applications with 17\%, Biological Applications with 11\% and Nuclear Engineering and Technology with 9\%. The remaining $18 \%$ were divided between Nuclear Physics and Chemistry, Biological Applications, Industrial and Hydrological Applications, and General Atomic Energy Development.

Agricultural Applications was also the major field of study undertaken by the Scientific Visitors and made up 34\% of those awards. Safety in Nuclear Energy made up 20\%, Medical Applications made up 14\% of those awards, and the number of SV's in each of the remaining fields was considerably smaller.

\section{Institutions Providing Training}

Since the inception of the IAEA Fellowship Program in 1958, over 500 U.S. institutions and thousands of individuals in federal, state and private organizations have lent their support to the program and provided the essential scientific, engineering, and technical expertise required to satisfy the diverse needs of the Fellows and of the countries they represented. 
Historically, training provided by universities and federal and state government facilities was approximately equal and jointly accounted for the large majority of all training opportunities. Medical schools typically trained only about $12 \%$ of Fellows. The balance of the training was provided by other institutions: private U.S. corporations and state institutions, nuclear power utilities, and mining exploration and processing facilities. About $13 \%$ of the Fellows also attended English language schools for a month or more of intensive English training in addition to their technical programs.

The list and types of institutions providing training for Fellows and SV's during 1997 are shown in Table A-5. Universities and federal and state government facilities remained the principal institutions providing training. Forty two universities and thirty three government facilities trained regular Fellows. Twenty medical schools or hospitals, thirteen other commercial or non-profit organizations, and two utilities also hosted Fellows. The distribution for the SV's was similar. Twelve Fellows attended English language school before beginning their technical training.

\section{Length of Tenure}

The length of the awards received by regular Fellows varied over a wide range depending on the type of training required and the prior knowledge and experience of the candidates. They last from one month to one year, with extensions possible. The average length has been running about six months.

The distribution is shown in Figure 4 and Table A-6. 85\% of Type I and Type II fellowships last between 1-7 months, an increase of $18 \%$ over 1996 . The lengths of the regular Fellow's fellowships decreased in 1997 over the previous year. The percentage that were greater than eight months duration was $13 \%$ in $1993,6 \%$ in $1994,8 \%$ in $1995,19 \%$ in 1996, and $13 \%$ in 1997. 
Figure 4. Duration of Fellowships by Type

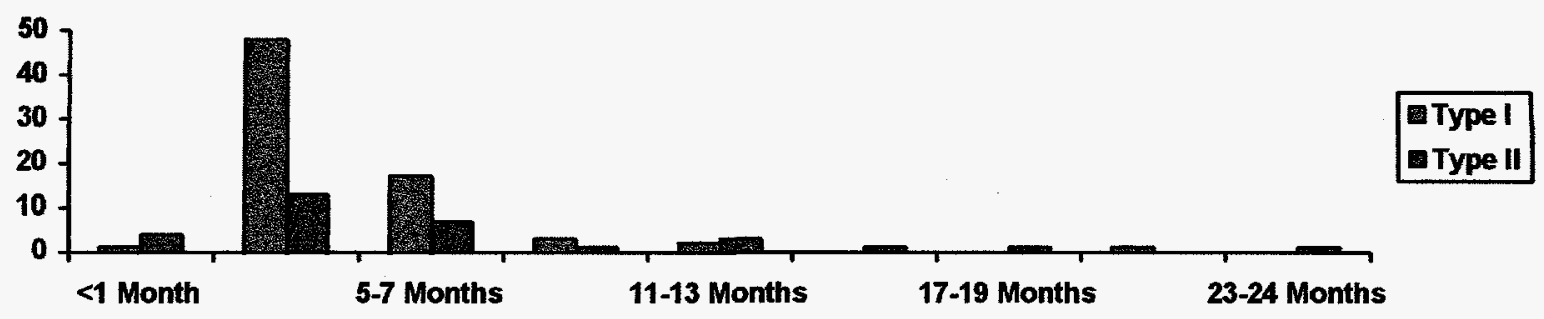

A significant number of hosts again expressed concern over the length of time requested for scientific visits. The requested visit time was often one week, and most prospective hosts were reluctant to devote an entire week to a visitor. Many times the host indicated that $\mathrm{s} /$ he could show the visitor everything relevant that was being done at the facility in one or two days. We were often obliged to arrange shorter term visits to more sites, something that took an inordinate amount of time to arrange. We often requested that the visitor be permitted access to the library for a day or two. This latter strategy actually proved to be a good one in most cases as the visitor could have access to journals that are often not available in his or her home country. Free use of the photocopying machine was granted in all cases. 
Appendix Tables

-

-

- 
Table A-1. Number of Fellows by Status and Type

Type I Sci Vstr Type II Total

1. Completed Tenure during 1997

2. On Tenure - December 31, 1997

Being Processed - December 31, 1997

$\begin{array}{rrrr}74 & 44 & 32 & 150 \\ 6 & 0 & 4 & 10 \\ 70 & 21 & 41 & 132\end{array}$

TOTAL

150

65

112

292 
Table A-2. Education, Age, and Gender Distribution of Fellows

\begin{tabular}{lrrrr}
\hline & Type I & Sci Vstr & Type II & Total \\
\hline Education & & & & \\
No degree & 0 & 2 & 0 & 2 \\
Baccalaureate & 24 & 10 & 10 & 44 \\
Master's & 33 & 12 & 16 & 61 \\
Doctorate & 12 & 17 & 7 & 36 \\
M.D./D.V.M & 11 & 3 & 3 & 17
\end{tabular}

Age

25-29

30-34

35-39

40-44

45-49

50-Over

No Report

$\begin{array}{rrrr}12 & 3 & 4 & 19 \\ 21 & 2 & 8 & 31 \\ 26 & 5 & 12 & 43 \\ 13 & 10 & 8 & 31 \\ 5 & 15 & 2 & 22 \\ 2 & 9 & 1 & 12 \\ 1 & 0 & 1 & 2\end{array}$

Gender

\begin{tabular}{llllr} 
Female & 17 & 15 & 10 & 42 \\
Male & 63 & 29 & 26 & 118 \\
\hline TOTAL & 80 & 44 & 36 & 160 \\
\hline
\end{tabular}


Table A-3. Home Countries

\begin{tabular}{|c|c|c|c|c|}
\hline Country & Type I & Sci Vstr & Type II & Total \\
\hline Argentina & 1 & 2 & $\mathbf{0}$ & 3 \\
\hline Bangladesh & 2 & $\mathbf{0}$ & $\mathbf{1}$ & 3 \\
\hline Brazil & 9 & 6 & 2 & 17 \\
\hline Bulgaria & 2 & 1 & 1 & 4 \\
\hline Chile & 1 & 4 & 1 & 6 \\
\hline Colombia & 1 & 0 & 2 & 3 \\
\hline Costa Rica & $\mathbf{0}$ & 1 & 1 & 2 \\
\hline Egypt, Arab Republic of & 4 & 1 & 9 & 14 \\
\hline Ethiopia & 0 & $\mathbf{0}$ & 2 & 2 \\
\hline Ghana & 2 & $\mathbf{0}$ & 0 & 2 \\
\hline Hungary & $\mathbf{0}$ & 7 & $\mathbf{0}$ & 7 \\
\hline Indonesia & 4 & $\mathbf{0}$ & 7 & 11 \\
\hline Israel & 1 & 1 & $\mathbf{0}$ & 2 \\
\hline Jordan & 1 & 1 & 1 & 3 \\
\hline Kazakhstan & 3 & $\mathbf{0}$ & $\mathbf{0}$ & 3 \\
\hline Korea & 11 & $\mathbf{0}$ & 1 & 12 \\
\hline Malaysia & 4 & 3 & 1 & 8 \\
\hline Mauritius & 2 & 2 & 0 & 4 \\
\hline Mexico & 1 & 3 & 1 & 5 \\
\hline Mongolia & $\mathbf{0}$ & $\mathbf{0}$ & 2 & 2 \\
\hline Morocco & $\mathbf{0}$ & $\mathbf{0}$ & 1 & 1 \\
\hline Nigeria & 1 & $\mathbf{0}$ & $\mathbf{0}$ & 1 \\
\hline Pakistan & 1 & $\mathbf{0}$ & $\mathbf{0}$ & 1 \\
\hline People's Republic of China & 3 & 1 & $\mathbf{0}$ & 4 \\
\hline Peru & 1 & $\mathbf{0}$ & $\mathbf{0}$ & 1 \\
\hline Phillipines & 3 & 1 & $\mathbf{0}$ & 4 \\
\hline Poland & $\mathbf{0}$ & 1 & $\mathbf{0}$ & 1 \\
\hline Portugal & 0 & 2 & $\mathbf{0}$ & 2 \\
\hline Romania & 3 & 0 & 0 & 3 \\
\hline Saudi Arabia & 2 & $\mathbf{0}$ & 0 & 2 \\
\hline Slovak Republic & 1 & $\mathbf{0}$ & $\mathbf{0}$ & 1 \\
\hline Slovenia & $\mathbf{0}$ & $\mathbf{0}$ & 2 & 2 \\
\hline Sri Lanka & 1 & $\mathbf{0}$ & 0 & 1 \\
\hline Tanzania & 0 & 0 & 1 & 1 \\
\hline Thailand & 2 & 2 & 0 & 4 \\
\hline Turkey & 9 & 1 & $\mathbf{0}$ & 10 \\
\hline Ukraine & 1 & 1 & 0 & 2 \\
\hline Uruguay & 1 & 2 & 0 & 3 \\
\hline Venezuela & 1 & 0 & 0 & 1 \\
\hline Vietnam & 1 & 1 & 0 & 2 \\
\hline TOTAL & 80 & 44 & 36 & 160 \\
\hline
\end{tabular}


Table A-4. Fields of Study

Type I Sci Vstrs Type II TOTAL

0 - Gen'l Atomic Energy Development

1 - Nuclear Physics

2 - Nuclear Chemistry

3 - Prospecting, Mining, and Processing

4 - Nuclear Engineering and Technology

5 - Agricultural Applications

6 - Medical Applications

7 - Biological Applications

8 - Industrial and Hydrological Application

9 - Safety in Nuclear Energy

1

3

1

0

9

18

15

15

4

TOTAL

80
2

0

1

0

5

15

6

2

9
3

1

4

4
3

1

16

46
26

6

9

9
43

14 
Table A-5. Institutions Providing Training

\section{A: Universities}

Type I SciVstr Type II TOTAL

University of California-Davis

Univ of California-Los Angeles

Univ of California-Riverside

Colorado State University

Cornell University/NY

University of Delaware

Eastern Virginia Medical School/Norfolk, VA

Fisk University, Nashville, TN

Florida International University

University of Florida

Georgetown University

University of Hawaii at Manoa

$\mathrm{U}$ of Illinois at Champaign/Urbana

Iowa State University

John Hopkins University/MD

Long Island Jewish Medical Center/NY

Louisiana State $U$ and A\&M College

University of Maryland

Massachusetts Inst of Technology

U of Massachusetts-Lowell

University of Miami/FL

Michigan State University

University of Minnesota/St Paul

University of Missouri-Columbia

University of New Mexico

North Carolina State U-Raleigh

Ohio State University

Oregon State University

The Pennsylvania State University

Purdue University/IN

State U. of New Jersey, Rutgers/NJ

University of Tennessee-Knoxville

Texas A\&M University

University of Texas,Austin

University of Texas-Dallas

Tuskegee University/A

University of Utah

Virginia Polytechnic Inst \& State U.

\begin{tabular}{|c|c|c|}
\hline 0 & 1 & 0 \\
\hline 1 & 0 & 0 \\
\hline 1 & 0 & 0 \\
\hline 1 & 0 & 0 \\
\hline 2 & 0 & 0 \\
\hline 1 & 0 & 0 \\
\hline 1 & 0 & 0 \\
\hline 1 & 0 & 0 \\
\hline 1 & 1 & 0 \\
\hline 1 & 0 & 0 \\
\hline 0 & 1 & 0 \\
\hline 3 & 1 & 0 \\
\hline 2 & 0 & 0 \\
\hline 1 & 1 & 3 \\
\hline 1 & 0 & 0 \\
\hline 0 & 0 & 1 \\
\hline 0 & 0 & 2 \\
\hline 1 & 0 & 1 \\
\hline 1 & 0 & 0 \\
\hline 0 & 0 & 1 \\
\hline 1 & 1 & 1 \\
\hline 0 & 1 & 0 \\
\hline 0 & 1 & 0 \\
\hline 0 & 1 & 0 \\
\hline 0 & 0 & 1 \\
\hline 1 & $\mathbf{0}$ & 0 \\
\hline 1 & 0 & 1 \\
\hline 0 & 1 & 0 \\
\hline 0 & 1 & 0 \\
\hline 0 & 2 & 0 \\
\hline 1 & $\mathbf{0}$ & 0 \\
\hline 1 & $\mathbf{0}$ & 0 \\
\hline 1 & 0 & 0 \\
\hline 1 & 0 & 0 \\
\hline 0 & 1 & 0 \\
\hline 0 & 0 & 2 \\
\hline 3 & 0 & 0 \\
\hline 1 & 0 & $\mathbf{0}$ \\
\hline
\end{tabular}


Table A-5. Institutions Providing Training (cont'd.)

B: Federal and State Facilities

Type I SciVstr Type II TOTAL

DOD-DNA/Beth MD

DOE/Grand Junction/CO

DOE-INEL

DoE-Argonne Nat Lab/Argon IL

DoE-Brookhaven Nat Lab/Uptn NY

DOE/Los Alamos NM

DoE-Oak Ridge Inst Sci and Edu/TN

DoE-Oak Ridge National Lab/TN

DoE-Sandia Nat'l Lab/Albuquerque NM

FDA/DC

HHS-Ctr Disease Contr and Prev/Atl GA

Natl Inst Stds andTech/Gaithrbg MD

Nuclear Reg Comm/Washington DC

Nuclear Reg Comm/Arlington TX

Tex Dept of Health/Austin TX

Tex Low-Level Radioactive Waste Auth

USDA/Bell CA

USDA/Beltsville MD

USDA/College-Station TX

USDA/Columbia MO

USDA/Fargo ND

USDA/Gainesville FL

USDA/Greenbelt MD

USDA/Honolulu HI

USDA/Miami FL

USDA/Mississippi State MS

USDA/Phoenix AZ

USDA/Stuttgart AR

USDA/Tifton GA

USDA/Waimanalo $\mathrm{HI}$

USDA/Weslaco TX

US Geol Survey/Denver CO

USGS/Woods Hole

\begin{tabular}{rrrr}
$\mathbf{0}$ & $\mathbf{0}$ & $\mathbf{1}$ & $\mathbf{1}$ \\
$\mathbf{0}$ & $\mathbf{1}$ & $\mathbf{0}$ & $\mathbf{1}$ \\
$\mathbf{2}$ & $\mathbf{3}$ & $\mathbf{0}$ & $\mathbf{5}$ \\
$\mathbf{3}$ & $\mathbf{1}$ & $\mathbf{1}$ & $\mathbf{5}$ \\
$\mathbf{4}$ & $\mathbf{2}$ & $\mathbf{0}$ & $\mathbf{6}$ \\
$\mathbf{0}$ & $\mathbf{0}$ & $\mathbf{5}$ & $\mathbf{5}$ \\
$\mathbf{7}$ & $\mathbf{1}$ & $\mathbf{1}$ & $\mathbf{9}$ \\
$\mathbf{1}$ & $\mathbf{2}$ & $\mathbf{0}$ & $\mathbf{3}$ \\
$\mathbf{1}$ & $\mathbf{1}$ & $\mathbf{1}$ & $\mathbf{3}$ \\
$\mathbf{0}$ & $\mathbf{1}$ & $\mathbf{0}$ & $\mathbf{1}$ \\
$\mathbf{0}$ & $\mathbf{1}$ & $\mathbf{0}$ & $\mathbf{1}$ \\
$\mathbf{0}$ & $\mathbf{1}$ & $\mathbf{0}$ & $\mathbf{1}$ \\
$\mathbf{2}$ & $\mathbf{7}$ & $\mathbf{3}$ & $\mathbf{1 2}$ \\
$\mathbf{1}$ & $\mathbf{0}$ & $\mathbf{0}$ & $\mathbf{1}$ \\
$\mathbf{0}$ & $\mathbf{1}$ & $\mathbf{0}$ & $\mathbf{1}$ \\
$\mathbf{0}$ & $\mathbf{1}$ & $\mathbf{0}$ & $\mathbf{1}$ \\
$\mathbf{0}$ & $\mathbf{3}$ & $\mathbf{0}$ & $\mathbf{3}$ \\
$\mathbf{1}$ & $\mathbf{1}$ & $\mathbf{0}$ & $\mathbf{2}$ \\
$\mathbf{0}$ & $\mathbf{1}$ & $\mathbf{0}$ & $\mathbf{1}$ \\
$\mathbf{0}$ & $\mathbf{0}$ & $\mathbf{1}$ & $\mathbf{1}$ \\
$\mathbf{1}$ & $\mathbf{0}$ & $\mathbf{1}$ & $\mathbf{2}$ \\
$\mathbf{0}$ & $\mathbf{1}$ & $\mathbf{0}$ & $\mathbf{1}$ \\
$\mathbf{1}$ & $\mathbf{0}$ & $\mathbf{0}$ & $\mathbf{1}$ \\
$\mathbf{1}$ & $\mathbf{0}$ & $\mathbf{0}$ & $\mathbf{1}$ \\
$\mathbf{0}$ & $\mathbf{1}$ & $\mathbf{0}$ & $\mathbf{1}$ \\
$\mathbf{1}$ & $\mathbf{0}$ & $\mathbf{0}$ & $\mathbf{1}$ \\
$\mathbf{0}$ & $\mathbf{2}$ & $\mathbf{0}$ & $\mathbf{2}$ \\
$\mathbf{0}$ & $\mathbf{0}$ & $\mathbf{1}$ & $\mathbf{1}$ \\
$\mathbf{0}$ & $\mathbf{0}$ & $\mathbf{1}$ & $\mathbf{1}$ \\
$\mathbf{2}$ & $\mathbf{0}$ & $\mathbf{0}$ & $\mathbf{2}$ \\
$\mathbf{0}$ & $\mathbf{4}$ & $\mathbf{0}$ & $\mathbf{4}$ \\
$\mathbf{0}$ & $\mathbf{3}$ & $\mathbf{0}$ & $\mathbf{3}$ \\
$\mathbf{1}$ & $\mathbf{0}$ & $\mathbf{0}$ & $\mathbf{1}$ \\
\hline & & & \\
\hline
\end{tabular}


Table A-5. Institutions Providing Training (cont'd.)

C: Medical Schools and Hospitals

Type I SciVstr Type II TOTAL

Baylor Coll Med/Houston

Colorado U., Denver

Columbia Presbyt/NY

Georgetown Sch Med/DC

Harvard Med Sch/Boston MA

Howard U Sch Med/Wash DC

Illinois U.-Medical Center, Chicago III

LA ST. U, Med Center-New Orleans LA

Mallinckrodt Inst/St.Louis, MO

Maryland, U. Sch Med.

Mass Univ Sch/Worcester MA

NW Tissue Center, Seattle, WA

Scripps Clinic/CA

St. Vincent Hospital, NY

Stanford Sch Med/Stanford, CA

Texas U Hith Sc/Antonio, TX

Tulane U Sch Med/New Orleans LA

$\begin{array}{llll}\mathbf{1} & \mathbf{0} & \mathbf{0} & \mathbf{1} \\ \mathbf{0} & \mathbf{1} & \mathbf{0} & \mathbf{1} \\ \mathbf{0} & \mathbf{1} & \mathbf{0} & \mathbf{1} \\ \mathbf{0} & \mathbf{0} & \mathbf{1} & \mathbf{1} \\ \mathbf{1} & \mathbf{0} & \mathbf{0} & \mathbf{1} \\ \mathbf{1} & \mathbf{0} & \mathbf{0} & \mathbf{1} \\ \mathbf{1} & \mathbf{0} & \mathbf{0} & \mathbf{1} \\ \mathbf{0} & \mathbf{0} & \mathbf{1} & \mathbf{1} \\ \mathbf{1} & \mathbf{0} & \mathbf{0} & \mathbf{1} \\ \mathbf{1} & \mathbf{0} & \mathbf{0} & \mathbf{1} \\ \mathbf{1} & \mathbf{0} & \mathbf{0} & \mathbf{1} \\ \mathbf{1} & \mathbf{1} & \mathbf{0} & \mathbf{2} \\ \mathbf{1} & \mathbf{0} & \mathbf{0} & \mathbf{1} \\ \mathbf{2} & \mathbf{0} & \mathbf{1} & \mathbf{3} \\ \mathbf{1} & \mathbf{0} & \mathbf{0} & \mathbf{1} \\ \mathbf{0} & \mathbf{1} & \mathbf{0} & \mathbf{1} \\ \mathbf{1} & \mathbf{0} & \mathbf{0} & \mathbf{1}\end{array}$


Table A-5. Institutions Providing Training (cont'd.)

D: Exploration, Mining and Processing

Type I SciVstr Type II TOTAL

Energy Fuels Nuclear, Inc/Denver CO

0

1

0

1

E: Utilities

Type I SciVstr Type II TOTAL

Baltimore Gas\&Elec/Calvert Cliffs MD

PECO-Peach Bottm/Delta PA

$\begin{array}{llll}0 & 2 & 0 & 2 \\ 0 & 0 & 1 & 1\end{array}$


Table A-5. Institutions Providing Training (cont'd.)

F: Other Commercial and Nonprofit

Type I SciVstr Type II TOTAL

ABB AMDATA INC/Windsor CT

FL Dept of Agri/Gainesville FL

Innovative Systems Software Idaho Falls

Medx Inc./Woods-Dale IIl

General Atomics/San-Diego CA

PA Regional Tissue Bank/Scranton PA

PLG/Newport Beach CA

SAIC

Scientech/Rockville, MD

Sonalysts/Waterford CT

Southwest Research Institue/San-Ant TX

Westinghouse Electric/Pittsb PA

$\begin{array}{llll}\mathbf{1} & \mathbf{0} & \mathbf{0} & \mathbf{1} \\ \mathbf{1} & \mathbf{0} & \mathbf{0} & \mathbf{1} \\ \mathbf{0} & \mathbf{2} & \mathbf{0} & \mathbf{2} \\ \mathbf{0} & \mathbf{0} & \mathbf{1} & \mathbf{1} \\ \mathbf{0} & \mathbf{0} & \mathbf{3} & \mathbf{3} \\ \mathbf{1} & \mathbf{0} & \mathbf{0} & \mathbf{1} \\ \mathbf{1} & \mathbf{0} & \mathbf{0} & \mathbf{1} \\ \mathbf{1} & \mathbf{1} & \mathbf{0} & \mathbf{2} \\ \mathbf{1} & \mathbf{0} & \mathbf{0} & \mathbf{1} \\ \mathbf{1} & \mathbf{0} & \mathbf{0} & \mathbf{1} \\ \mathbf{1} & \mathbf{0} & \mathbf{0} & \mathbf{1} \\ \mathbf{1} & \mathbf{2} & \mathbf{0} & \mathbf{3}\end{array}$

G: English Language Schools

Type I SciVstr Type II TOTAL

ELS/Atlanta GA

ELS/New Haven CT

ELS/Chicago-River Forest IL

ELS/College of Mt St Vincent NY

ELS/Denver CO

ELS/Houston TX

ELS/Melbourne FL

ELS/Oakland CA

ELS/Orange CA

ELS/Petersburg FL

ELS/Philadelphia PA

$\begin{array}{llll}\mathbf{1} & \mathbf{0} & \mathbf{0} & \mathbf{1} \\ \mathbf{1} & \mathbf{0} & \mathbf{0} & \mathbf{1} \\ \mathbf{1} & \mathbf{0} & \mathbf{1} & \mathbf{2} \\ \mathbf{1} & \mathbf{0} & \mathbf{0} & \mathbf{1} \\ \mathbf{1} & \mathbf{0} & \mathbf{0} & \mathbf{1} \\ \mathbf{0} & \mathbf{0} & \mathbf{1} & \mathbf{1} \\ \mathbf{1} & \mathbf{0} & \mathbf{0} & \mathbf{1} \\ \mathbf{1} & \mathbf{0} & \mathbf{0} & \mathbf{1} \\ \mathbf{1} & \mathbf{0} & \mathbf{0} & \mathbf{1} \\ \mathbf{0} & \mathbf{0} & \mathbf{1} & \mathbf{1} \\ \mathbf{1} & \mathbf{0} & \mathbf{0} & \mathbf{1}\end{array}$


Table A-6. Length of Tenure of Completed Fellowships

\begin{tabular}{lrrrr}
\hline & Type I & Sci Vstr & Type II & Total \\
\hline Less Than 1 Month & 1 & 44 & 4 & 49 \\
1 - 4 Months & 56 & 0 & 18 & 74 \\
5 - 7 Months & 17 & 0 & 7 & 24 \\
8 - 10 Months & 3 & 0 & 1 & 4 \\
$11-13$ Months & 2 & 0 & 3 & 5 \\
$14-16$ Months & 0 & 0 & 1 & 1 \\
17-24 Months & 1 & 0 & 2 & 3 \\
\hline TOTAL & 80 & 44 & 36 & 160
\end{tabular}

